\title{
Pengaruh pH Larutan Antosianin Strawberry dalam Prototipe Dye Sensitized Solar Cell (DSSC)
}

\author{
Mochamad Choirul Misbachudin, ${ }^{*}$ Ferdy S. Rondonuwu, dan Adita Sutresno ${ }^{\dagger}$ \\ Progam Studi Pendidikan Fisika, dan Progam Studi Fisika, Fakultas Sains dan Matematika \\ Universitas Kristen Satya Wacana, Jl. Diponegoro No. 52-60, Salatiga 50711
}

\begin{abstract}
Intisari
Telah difabrikasi prototipe Dye Sensitized Solar Cell (DSSC) dengan memanfaatkan ekstrak antosianin strawberry sebagai fotosensitizer. DSSC ini terdiri dari sepasang substrat kaca berlapis ITO sebagai elektroda dan counter elektroda. Pada elektroda dideposisikan lapisan nanokristal $\mathrm{TiO}_{2}$ berpori sebagai fotoanoda dan disensitisasi dye antosianin, sedangkan counter elektroda dideposisikan lapisan karbon. Kedua elektroda disusun dengan struktur sandwich dengan dipisahkan oleh elektrolit redoks $\left(\mathrm{I}^{-} / \mathrm{I}_{3}^{-}\right)$. Sel surya direndam dalam dye antosianin dengan $\mathrm{pH}$ yang berbeda, yaitu $\mathrm{pH} 3,0 ; \mathrm{pH}$ 2,5; dan $\mathrm{pH} 2,0$. Hasil pengujian sel surya menunjukkan bahwa sel surya yang direndam dengan $\mathrm{pH}$ 2,0 memiliki keluaran yang paling tinggi, dimana arus rangkaian pendek $\left(\mathrm{I}_{s c}\right)$ yang didapatkan sebesar $45 \mu \mathrm{A}$ dan tegangan rangkaian buka $\left(\mathrm{V}_{o c}\right)$ sebesar $321 \mathrm{mV}$, serta besar rapat arus $\left(\mathrm{J}_{s c}\right)$ adalah $20 \mu \mathrm{A} / \mathrm{cm}^{2}$. Sedangkan efisiensi konversi energinya sebesar $2,560 \times 10^{-3} \%$.
\end{abstract}

\section{ABSTRACT}

The prototype of Dye Sensitized Solar Cell (DSSC) has been fabricated using anthocyanin extract from fresh strawberry as the photosensitizer. This DSSC consist of a pair of ITO-coated glass substrate as the electrode and counter electrode. Permeable $\mathrm{TiO}_{2}$ nanocrystal layer was deposited as fotoanoda and anthocyanin dye sensitized at the electrode, while the counter electrode was deposited carbon layer. Both electrodes were arranged in sandwich structure, separated by redox electrolyte $\left(\mathrm{I}^{-} / \mathrm{I}_{3}^{-}\right)$. Solar cell was soaked in anthocyanin dye with different $\mathrm{pH}: \mathrm{pH} 3.0, \mathrm{pH} 2.5$, and $\mathrm{pH} 2.0$. The results showed that the solar cell soaked with $\mathrm{pH} 2.0$ has the highest output, where it is obtained $45 \mu \mathrm{A}$ of the short-circuit current $\left(\mathrm{I}_{s c}\right)$ and $321 \mathrm{mV}$ of the open-circuit voltage $\left(\mathrm{V}_{o c}\right)$, and $20 \mu \mathrm{A} / \mathrm{cm}^{2}$ of current density $\left(\mathrm{J}_{s c}\right)$. While the energy conversion efficiency is $2.560 \times$ $10^{-3} \%$.

KATA KUNCI: anthocyanin, pH, dye-sensitizer, DSSC

\section{PENDAHULUAN}

\section{Sumber Energi Terbarukan}

Kemajuan pembangunan pada bidang teknologi, industri dan informasi membawa dampak terhadap meningkatnya kebutuhan energi. Selama ini kebutuhan energi masih mengandalkan bahan bakar fosil, sehingga berdampak semakin berkurangnya ketersedianan sumber daya energi fosil khususnya minyak bumi. Seperti yang diketahui bahwa sumber energi fosil merupakan sumber energi yang tidak dapat diperbaharui, dan proses pembentukannya dibutuhkan waktu yang sangat lama. Untuk itu diperlukan sumber energi alternatif yang dapat menggantikan sumber energi fosil. Sumber energi alternatif yang dapat dijadikan solusi adalah sistem konversi energi yang memanfaatkan sumber daya energi terbarukan, seperti: energi matahari, energi angin, energi air,

\footnotetext{
*E-MAIL: choirul_mcmeyahoo.com

$\dagger$ E-MAIL: aditaestaff.uksw.edu
}

biomassa, panas bumi [1, 2]. Sumber energi matahari sangat memungkinkan untuk dijadikan sebagai solusi pengganti dari sumber daya energi fosil, karena sumber energi ini tersedia dalam jumlah yang sangat besar dan melimpah.

Michael Grätzel merupakan seorang peneliti yang pertama kali berhasil mengembangkan sistem sel surya tersintesa pewarna (Dye Sensitized Solar Cell) [3, 4]. Bio sel surya yang dikembangkan Grätzel ini proses pembuatannya cukup sederhana serta biayanya relatif murah, dan bahan dasarnya mudah diperoleh di pasaran [5]. Namun sel surya ini masih perlu banyak pengembangan lebih lanjut guna meningkatkan efisiensi konversi energi photo elektrokimianya.

Dalam penelitian sebelumnya [6], penulis telah melakukan kajian awal untuk mengetahui bagaimana pengaruh jumlah konsentrasi antosianin terhadap hasil keluaran sel surya DSSC. Dalam penelitian tersebut dilakukan ekstraksi antosianin strawberry dengan beberapa variasi perbandingan campuran pelarut, yaitu antara metanol, asam asetat, dan aquades. Dari hasil pengujian sel surya menunjukkan bahwa perbandingan yang paling efektif untuk ekstraksi antosianin strawberry adalah dengan campuran pelarut metanol, asam asetat, dan aquades yaitu 25:4:21 [6]. Pada penelitian lain [7], telah dilakukan kajian terhadap karateristik arus dan te- 


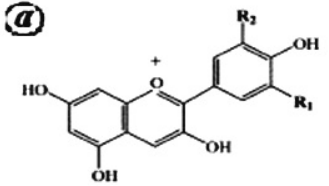

(b)

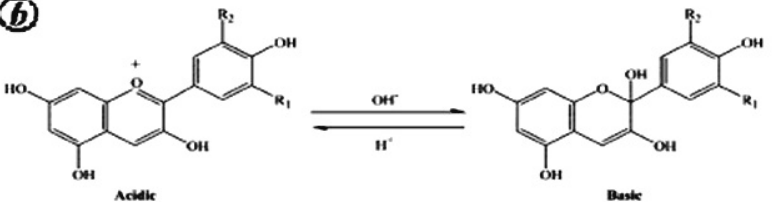

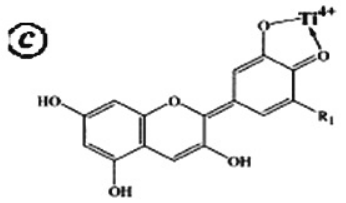

Gambar 1: a). Struktur kimia dasar dari antosianin, b). Dua macam struktur kimia antosianin dalam media asam dan basa, c). Rangkaian mekanisme antosianin dengan $\mathrm{TiO}_{2}[8]$.

gangan sel surya DSSC dengan variasi pengenceran ekstrak dye antosianin strawberry. Hasil pengujian sel surya DSSC menunjukkan bahwa ekstrak antosianin strawberry tanpa pengenceran memiliki arus rangkaian pendek $\left(\mathrm{I}_{s c}\right)$ dan tegangan rangkaian buka $\left(\mathrm{V}_{o c}\right)$ yang paling besar. Dengan kata lain semakin tinggi konsentrasi antosianin, maka semakin tinggi pula arus dan tegangan keluaran yang dihasilkan [7].

Pada artikel ini dilaporkan kajian tentang pengaruh $\mathrm{pH}$ larutan antosianin terhadap efisiensi DSSC.

\section{Antosianin}

Antosianin merupakan pigmen larut air yang secara alami terdapat pada berbagai jenis tumbuhan dan buah-buahan. Pigmen tersebut akan memberikan warna merah, biru dan ungu pada buah, bunga dan daun yang masuk dalam klas flavonoids. Senyawa antosionin yang paling banyak ditemukan adalah pelargonidin (orange), cyanidin (orangemerah), peonidin (orange-merah), delphinidin (biru-merah), petunidin (biru-merah), dan malvidin (biru-merah) [8]. Antosianin strawberry merupakan senyawa yang termasuk dalam gugusan pelargonidin.

Antosianin memiliki struktur kimia yang terdiri dari kation tujuh hydroxy flavilium, molekul ini berfungsi dalam penyerapan cahaya dan membentuk warna seperti ditunjukkan pada Gambar 1. Antosianin yang terbentuk secara alami mempunyai group hydroxyl $\left(\mathrm{HO}^{-}\right)$pada posisi 3 dan selalu terhubung dengan molekul glukosa yang dibutuhkan untuk kesetimbangan termal dan posisi 5 terdapat satu atau lebih group hydroxyl atau methoxy $\left(\mathrm{CH}_{3} \mathrm{O}^{-}\right)$pada cincin $\mathrm{B}$. Ragam warna yang diperlihatkan oleh antosianin tergantung pada nomor dan posisi dari gugusan yang ada [8].

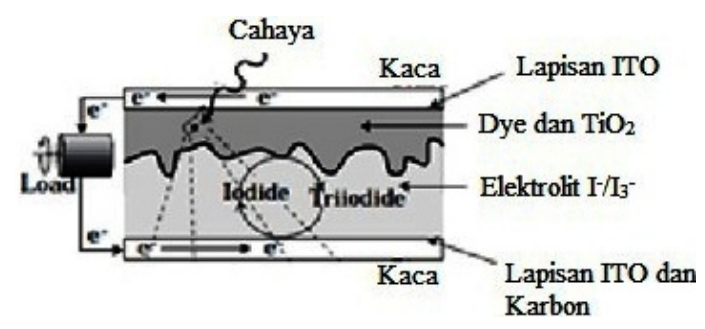

Gambar 2: Skema DSSC [11] dengan modifikasi gambar.

\section{Derajat Keasaman (pH) Antosianin}

$\mathrm{pH}$ (potential of Hydrogen) atau derajat keasaman merupakan ukuran konsentrasi ion hidrogen yang menunjukkan keasaman atau kebasaan suatu zat. Besarnya nilai $\mathrm{pH}$ bervariasi, yaitu dari 1 hingga 14. Larutan yang netral memiliki $\mathrm{pH}$ bernilai 7, sedangkan larutan asam memiliki nilai $\mathrm{pH}<7$, dan larutan basa memiliki nilai $\mathrm{pH}>7$.

Kondisi pH sangat mempengaruhi stabilitas/kesetimbangan dari larutan ekstrak antosianin. Larutan antosianin memiliki lima bentuk kesetimbangan yang bergantung pada kondisi $\mathrm{pH}$, yaitu kation flavilium, basa karbinol, kalkon, basa quinonoidal, dan quinonoidal anionic. Ketika dalam kondisi $\mathrm{pH}$ yang sangat asam, antosianin memiliki bentuk kation flavilium, dimana antosianin berada pada kondisi paling stabil dan paling berwarna. Sedangkan pada $\mathrm{pH}$ yang lebih basa, antosianin akan berwarna kuning (bentuk kalkon), berwarna biru (bentuk quinouid), atau tidak berwarna (basa karbinol) [9].

\section{Dye Sensitized Solar Cell (DSSC)}

DSSC terdiri dari sepasang substrat kaca berlapis ITO (indium-tin oxide) yang berperan sebagai elektroda dan counter elektroda. Pada elektroda dideposisikan lapisan nanokristal $\mathrm{TiO}_{2}$ berpori sebagai fotoanoda, dan disensitisasi dye antosianin sebagai fotosensitizer sel surya. Sedangkan untuk counter elektroda dilapisi katalis dengan dideposisi menggunakan lapisan karbon untuk mempercepat reaksi redoks. Kedua elektroda kemudian disusun dengan struktur sandwich dengan dipisahkan oleh elektrolit redoks $\left(\mathrm{I}^{-} / \mathrm{I}_{3}^{-}\right)$, seperti yang tunjukkan pada Gambar $2[5,10,11]$.

Skema prinsip kerja dari DSSC ditunjukkan pada Gambar 3. Energi foton diserap oleh dye (D) sehingga elektron berpindah dari level energi terendah (HOMO) ke level energi tertinggi (LUMO).

$$
D+\text { cahaya } \rightarrow D^{*}
$$

Pada keadaan tereksitasi $\left(\mathrm{D}^{*}\right)$ dye menginjeksi elektron menuju pita konduksi semikonduktor $\mathrm{TiO}_{2}$, kemudian elektron tersebut melewati $\mathrm{TiO}_{2}$ menuju elektroda ITO dan selanjutnya elektron mengalir menuju elektroda lawan (counter electrode) melalui rangkaian eksternal.

$$
D^{*}+\mathrm{TiO}_{2} \rightarrow e^{-}\left(\mathrm{TiO}_{2}\right)+D^{+}
$$




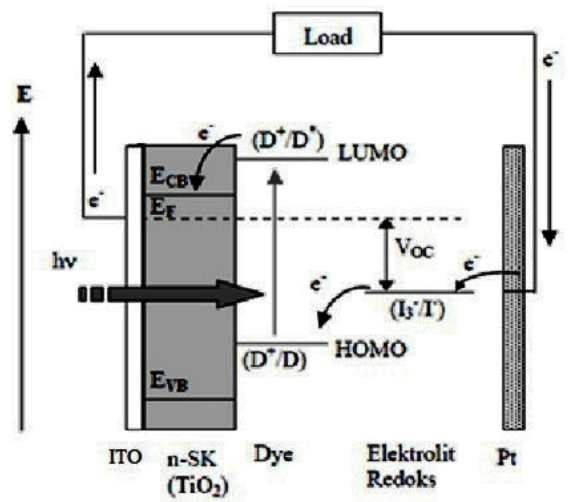

Gambar 3: Prinsip kerja sel surya nanopartikel $\mathrm{TiO}_{2}$ tersensitisasi dye [5] dengan modifikasi gambar.

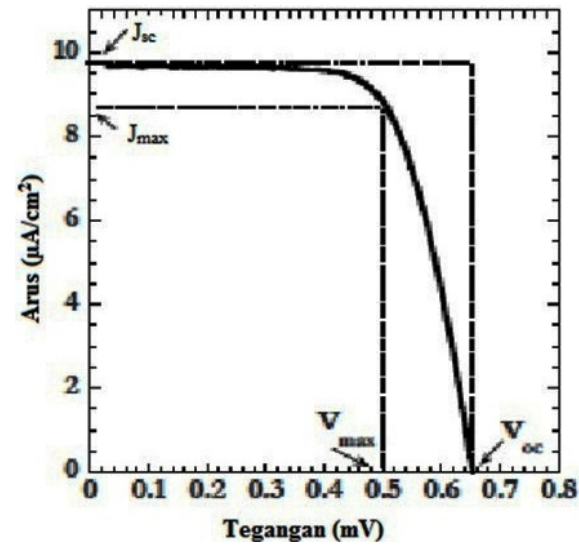

Gambar 4: Kurva Arus-Tegangan (J-V) sel surya DSSC [12] dengan modifikasi gambar.

Selanjutnya elektron masuk kembali ke dalam sel dan mereduksi $\left(\mathrm{I}^{+}\right)$yang ada pada elektrolit. Setelah itu dye teroksidasi $\left(\mathrm{D}^{+}\right)$menerima elektron dari $\left(\mathrm{I}_{3}^{-}\right)$dan tergenerasi kembali menjadi (D) [5].

$$
\begin{array}{r}
D^{+}+e^{-}\left(\mathrm{TiO}_{2}\right) \rightarrow D+\mathrm{TiO}_{2} \\
2 D^{+}+3 I^{-} \rightarrow 2 D+I_{3}^{-}
\end{array}
$$

\section{Karakteristik Arus-Tegangan Sel Surya DSSC}

Pengukuran konversi energi cahaya menjadi energi listrik digambarkan dalam kurva arus-tegangan $(\mathrm{J}-\mathrm{V})$ seperti pada Gambar 4.

Gambar 4 menunjukkan tegangan rangkaian buka atau tegangan open circuit $\left(\mathrm{V}_{o c}\right)$, tegangan maksimum $\left(\mathrm{V}_{\max }\right)$, rapat arus rangkaian pendek atau rapat arus sort circuit $\left(\mathrm{J}_{s c}\right)$, dan rapat arus maksimum $\left(\mathbf{J}_{\max }\right)$. Tegangan rangkaian buka $\left(\mathrm{V}_{o c}\right)$ dihasilkan ketika sel dalam kondisi open circuit sehingga tidak ada arus yang mengalir dalam rangkaian. Sedangkan arus rangkaian pendek $\left(\mathbf{J}_{s c}\right)$ dihasilkan pada saat sel dalam kondisi sort circuit sehingga arus akan mengalir [12]. Selain itu karakteristik lainnya yang mempengaruhi efisiensi sel surya adalah nilai faktor pengisian atau fill factor (FF). Nilai dari fill factor (FF) dapat dihitung dengan menggunakan persamaan:

$$
F F=\frac{J_{\max } \times V_{\max }}{J_{s c} \times V_{s c}}
$$

dengan,

$$
P_{\max }=J_{\max } \times V_{\max }=J_{s c} \times V_{o c} \times F F
$$

Sehingga untuk menghitung efisiensi konversi energi $(\eta)$ dari sel surya DSSC dapat dicari dengan menggunakan persamaan:

$$
\begin{aligned}
\eta & =\frac{P_{\max }}{P_{i n}} \times 100 \% \\
& =\frac{J_{s c} \times V_{o c} \times F F}{P_{i n}} \times 100 \%
\end{aligned}
$$

\section{METODOLOGI PENELITIAN}

\section{Bahan dan Alat}

Bahan yang digunakan dalam penelitian ini antara lain adalah buah strawberry, substrat kaca berlapis ITO (indium-tin oxide)), Titanium dioxide $\left(\mathrm{TiO}_{2}\right)$, Potassium Iodide (KI), Iodine $\left(\mathrm{I}_{2}\right)$, Polyethylene Glycol (PEG), aseton, etanol, metanol, asam asetat, dan aquades.

\section{Preparasi Elektroda $\mathrm{TiO}_{2}$}

Dalam preparasi elektroda $\mathrm{TiO}_{2}$, tahap pertama substrat kaca berlapis ITO dicuci dan dibilas dengan menggunakan aseton. Kemudian diukur resistansinya dengan menggunakan multimeter digital dan selanjutnya pada sisi kaca yang berlapis ITO ditutup dengan menggunakan isolatipe seperti pada Gambar 5. Tahap kedua adalah pembuatan pasta $\mathrm{TiO}_{2}$, yaitu dilakukan dengan menambahkan $15 \mathrm{ml}$ etanol pada 3,5 gr koloid $\mathrm{TiO}_{2}$, dan kemudian diaduk menggunakan magnetic stirer selama 30 menit. Tahap selanjutnya pasta $\mathrm{TiO}_{2}$ dideposisikan pada substrat kaca berlapis ITO dan kemudian dipanaskan dengan temperatur $200^{\circ} \mathrm{C}$ selama \pm 20 menit.

\section{Ekstraksi Dye Antosianin}

Buah strawberry yang masih segar ditimbang sebanyak 40 gram dan ditumbuk dengan mortar sampai halus. Kemudian dimasukkan dalam tabung erlenmeyer yang telah dilapisi dengan alumunium foil, dan selanjutnya direndam dengan campuran pelarut $50 \mathrm{ml}$ metanol, $8 \mathrm{ml}$ asam asetat, dan $42 \mathrm{ml}$ aquades selama 24 jam. Setelah itu, ekstrak antosianin disaring dengan menggunakan kertas saring dan dimasukkan ke dalam botol gelap atau botol yang telah dilapisi dengan alumunium foil (Gambar 6). Untuk membuat variasi larutan ekstrak antosianin strawberry dengan $\mathrm{pH}$ yang berbeda, maka 


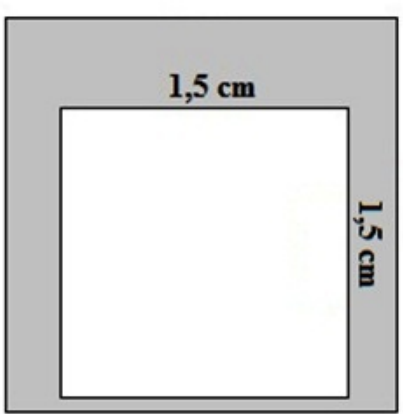

Gambar 5: Skema Deposisi $\mathrm{TiO}_{2}$ pada kaca ITO.

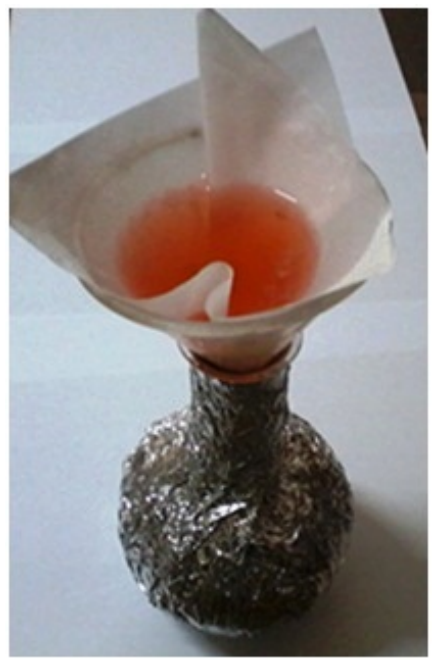

Gambar 6: Ekstraksi Antosianin Strawberry.

dilakukan ekstraksi dengan pengurangan serta penambahan asam asetat pada masing-masing campuran pelarut (Gambar 7). Dalam hal ini, menggunakan campuran pelarut $50 \mathrm{ml}$ metanol, $4 \mathrm{ml}$ asam asetat, $42 \mathrm{ml}$, serta campuran pelarut $50 \mathrm{ml}$ metanol, $12 \mathrm{ml}$ asam asetat, $42 \mathrm{ml}$. Tahap selanjutnya, ketiga larutan ekstrak antosianin kemudian diukur $\mathrm{pH}-$ nya dengan menggunakan $\mathrm{pH}$ Indikator Acilit.

\section{Preparasi Elektrolit}

Pembuatan elektrolit terdiri dari 8,30 gr potassium iodide

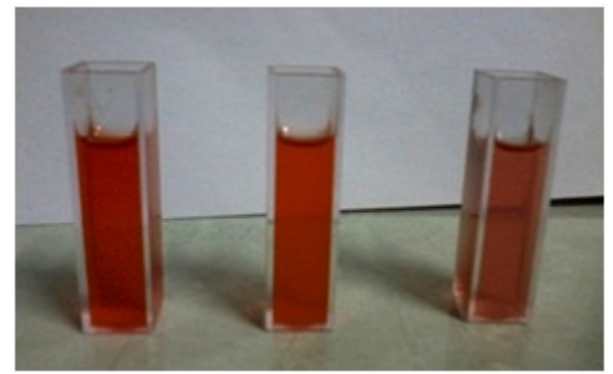

Gambar 7: Hasil Ekstrak Antosianin Strawberry.

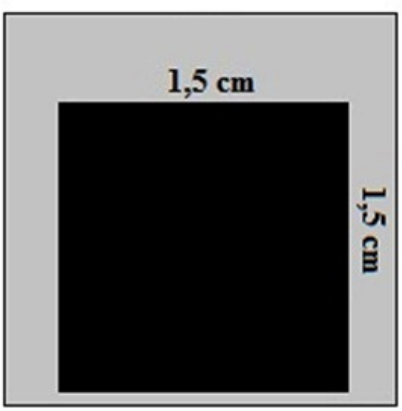

Gambar 8: Skema Deposisi Karbon pada Kaca ITO.

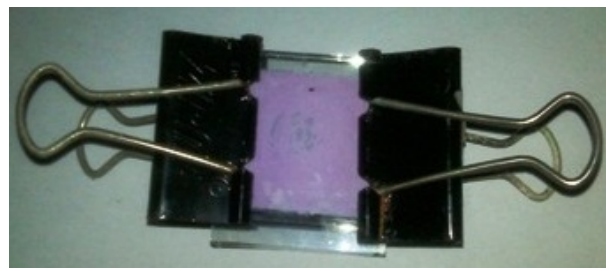

Gambar 9: Struktur sandwich DSSC.

(KI) dan 1,26 gr iodine $\left(\mathrm{I}_{2}\right)$ yang kemudian dilarutkan dalam $100 \mathrm{ml}$ PEG [9]. Selanjutnya larutan elektrolit tersebut diaduk dengan menggunakan magnetic stirrer selama \pm 30 menit. Larutan elektrolit yang sudah jadi kemudian disimpan dalam botol berwarna gelap atau botol yang telah dlapisi dengan alumunium foil.

\section{Preparasi Elektroda Karbon}

Kaca berlapis ITO diukur resistansiya dengan menggunakan multimeter digital, dan selanjutnya pada sisi kaca yang berlapis ITO ditutup dengan menggunakan isolatipe seperti pada Gambar 8. Untuk pembuatan larutan karbon, yaitu langkah pertama karbon dari pensil $2 \mathrm{~B}$ dihaluskan dengan mortar, lalu ditimbang sebanyak 3,5 gr. Selanjutnya dicampur dengan etanol sebanyak $15 \mathrm{ml}$, dan diaduk dengan menggunakan magnetic stirrer selama \pm 30 menit. Setelah itu, langkah selanjutnya pasta karbon dideposisikan pada substrat kaca berlapis ITO dan kemudian dipanaskan dengan temperatur $200^{\circ}$ selama \pm 20 menit.

\section{Pembuatan DSSC}

Elektroda $\mathrm{TiO}_{2}$ yang telah dibuat kemudian direndam dalam larutan ekstrak antosianin, masing-masing dengan pH 3,0; 2,5; dan 2,0 selama 24 jam. Setelah itu, elektroda $\mathrm{TiO}_{2}$ yang telah direndam dalam larutan ekstrak antosianin, kemudian diangkat dan dikeringkan dengan kertas tisu. Kemudian elektroda $\mathrm{TiO}_{2}$ - elektrolit - elektroda karbon, disusun dengan struktur sandwich seperti pada Gambar 9. 


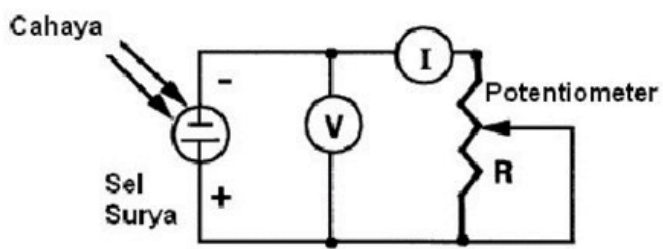

Gambar 10: Rangkaian pengukuran DSSC [5].

\section{Karakterisasi DSSC}

Sel surya yang telah dibuat kemudian diukur arus dan tegangannya (I-V) dengan menggunakan multimeter digital untuk menganalisis karakteristik hasil keluaran dari sel surya. Pengukuran dilakukan menggunakan sumber cahaya lampu xenon dengan intensitas $1000 \mathrm{~W} / \mathrm{m}^{2}$ pada jarak $30 \mathrm{~cm}$. Untuk mengatur arus maupun tegangan keluaran pada sel surya maka dipasang resistor dengan berbagai variasi hambatan pada rangkaian pengukur (Gambar 10).

\section{HASIL DAN PEMBAHASAN}

Setelah DSSC dirangkai kemudian dilakukan pengujian untuk mengetahui karakteristik arus (I) dan tegangannya (V) dengan menggunakan multimeter digital. Hasil pengukuran dari sel surya kemudian digambarkan dalam grafik hubungan arus terhadap tegangan (I-V) seperti pada Gambar 11.

Dari grafik hubungan arus terhadap tegangan $(\mathrm{J}-\mathrm{V})$ yang ditunjukkan pada Gambar 11, terlihat bahwa masing-masing sel surya DSSC yang direndam dalam larutan antosianin dengan $\mathrm{pH} 3,0 ; 2,5$; dan 2,0 memiliki arus (I) maupun tegangan (V) keluaran yang berbeda-beda. Sel surya yang direndam dalam larutan ekstrak antosianin strawberry dengan pH 3,0 memiliki keluaran yang paling kecil yaitu dengan arus rangkaian pendek $\left(\mathrm{I}_{s c}\right)$ sebesar 21,00 $\mu$ A dan tegangan rangkaian buka $\left(\mathrm{V}_{o c}\right)$ sebesar 3,60 mV. Arus maksimum yang dihasilkan $\left(\mathrm{I}_{\max }\right)$ sebesar 14,00 $\mu \mathrm{A}$, tegangan maksimum $\left(\mathrm{V}_{\max }\right)$ sebesar 2,60 $\mathrm{mV}$, sedangkan rapat arus $\left(\mathrm{J}_{s c}\right)$ pada luasan $2,25 \mathrm{~cm} 2$ adalah sebesar $9,34 \mu \mathrm{A} / \mathrm{cm}^{2}$. Selanjutnya untuk sel surya yang direndam dalam larutan ekstrak antosianin strawberry dengan $\mathrm{pH}$ 2,5 memiliki arus rangkaian pendek $\left(\mathrm{I}_{s c}\right)$ sebesar 30,00 $\mu \mathrm{A}$ dan tegangan rangkaian buka $\left(\mathrm{V}_{o c}\right)$ sebesar 31,60 $\mathrm{mV}$. Sementara itu arus maksimum $\left(\mathrm{I}_{\max }\right)$ yang dihasilkan yaitu sebesar $19 \mu \mathrm{A}$, dengan tegangan maksimum $\left(\mathrm{V}_{\max }\right)$ sebesar 21,10 $\mathrm{mV}$. Kemudian untuk rapat arus $\left(\mathrm{J}_{s c}\right)$ yang didapatkan dari sel surya ini adalah $13,34 \mu \mathrm{A} / \mathrm{cm}^{2}$. Untuk pengukuran pada sel surya yang direndam dalam larutan ekstrak antosianin strawberry dengan $\mathrm{pH}$ 2,0 (Gambar 11(c)) memiliki hasil keluaran yang paling besar, dimana arus rangkaian pendek $\left(\mathrm{I}_{s c}\right)$ yang didapatkan sebesar 45,00 $\mu \mathrm{A}$ dan tegangan rangkaian buka $\left(\mathrm{V}_{o c}\right)$ sebesar $321,00 \mathrm{mV}$. Sedangkan arus maksimum $\left(\mathrm{I}_{\max }\right)$ yang dihasilkan sebesar $31,00 \mu \mathrm{A}$, dan tegangan maksimumnya $\left(\mathrm{V}_{\max }\right)$ sebesar $190,00 \mathrm{mV}$, serta besar rapat arus $\left(J_{s c}\right)$ pada luasan $2,25 \mathrm{~cm}^{2}$ adalah $20,00 \mu \mathrm{A} / \mathrm{cm}^{2}$. Dengan demikian, maka dapat ditentukan parameter-parameter hasil keluaran dari sel surya seperti yang ditunjukkan pada Tabel I.

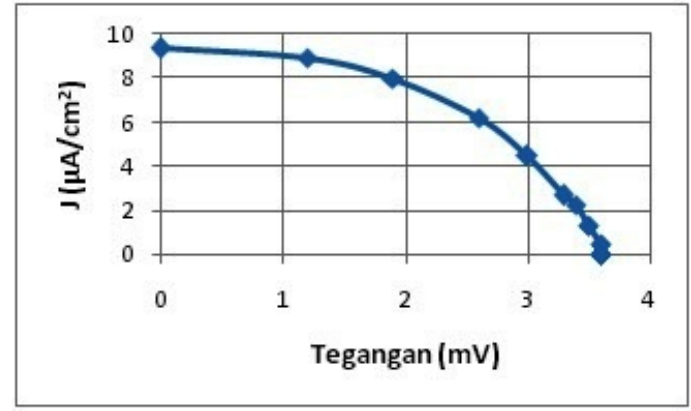

(a) $\mathrm{pH} 3,0$

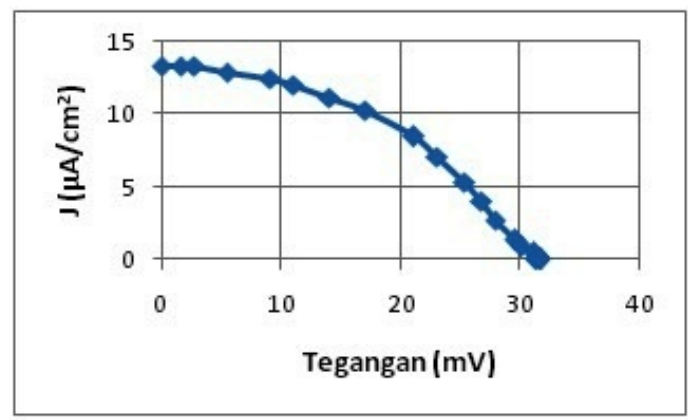

(b) $\mathrm{pH} 2,5$

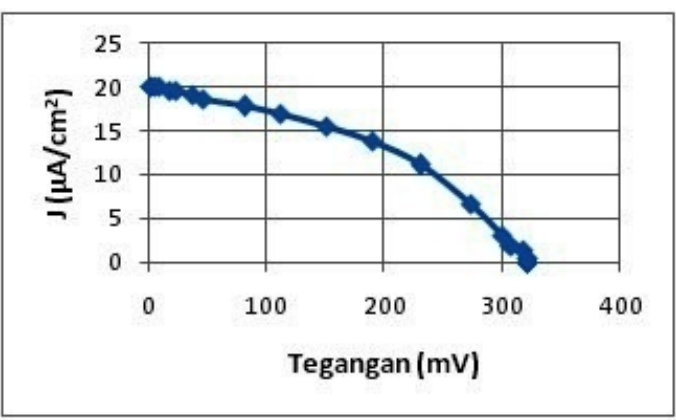

(c) $\mathrm{pH} 2,0$

Gambar 11: Grafik hubungan Arus terhadap Tegangan DSSC dengan dye antosianin.

TABEL I: Parameter-parameter Sel Surya DSSC

\begin{tabular}{|c|c|c|c|c|c|c|c|}
\hline $\begin{array}{l}\text { pH Larutan } \\
\text { Ekstrak } \\
\text { Antosianin } \\
\text { Strawberry }\end{array}$ & $\begin{array}{c}\mathrm{I}_{s c} \\
(\mu \mathrm{A})\end{array}$ & $\begin{array}{c}\mathrm{V}_{o c} \\
(\mathrm{mV})\end{array}$ & $\begin{array}{l}\mathrm{I}_{\max } \\
(\mu \mathrm{A})\end{array}$ & $\begin{array}{l}\mathrm{V}_{\max } \\
(\mathrm{mV})\end{array}$ & $\begin{array}{c}\mathrm{Jsc} \\
\left(\mu \mathrm{A} / \mathrm{cm}^{2}\right)\end{array}$ & FF & $\begin{array}{c}\eta \\
\left(10^{-3} \%\right)\end{array}$ \\
\hline 3,0 & 21,00 & 3,60 & 14,00 & 2,60 & 9,34 & 0,48 & 0,016 \\
\hline 2,5 & 30,00 & 31,60 & 19,00 & 21,10 & 13,34 & 0,42 & 0,170 \\
\hline 2,0 & 45,00 & 321,00 & 31,00 & 190,00 & 20,00 & 0,40 & 2,560 \\
\hline
\end{tabular}

Pada Tabel I terlihat bahwa nilai efisiensi konversi energi $(\eta)$ untuk sel surya yang direndam dalam larutan ekstrak antosianin strawberry dengan $\mathrm{pH}$ 3,0 masih sangat kecil yaitu sebesar $0,016 \times 10^{-3} \%$. Dan untuk sel surya yang direndam dalam larutan ekstrak antosianin strawberry dengan $\mathrm{pH}$ 2,5 adalah $0,170 \times 10^{-3} \%$. Sedangkan sel surya yang direndam dalam larutan ekstrak antosianin strawberry dengan pH 2,0 memiliki efisiensi konversi energi yang paling tinggi 
dibanding dengan yang lain yaitu sebesar $2,560 \times 10^{-3}$. Hal ini terjadi karena ketika dalam kondisi $\mathrm{pH}$ yang rendah (sangat asam), antosianin berada pada kondisi paling stabil dan paling berwarna, sehingga efisiensi yang dihasilkan memiliki nilai yang paling tinggi. Namun pada penelitian lain dengan menggunakan ekstrak antosianin kol merah menunjukkan hasil yang berlawanan, dimana nilai efisiensi paling besar dihasilkan dengan $\mathrm{pH}$ larutan yang paling tinggi. Hasil ini disebabkan karena struktur kimia antosianin strawberry dan kol merah yang berbeda. Nilai efisiensi konversi energi yang didapatkan ini masih sangat rendah jika dibandingkan dengan yang didapatkan oleh E. Jarkko yang juga menggunakan strawberry sebagai dye, dan berhasil mendapatkan nilai efisiensi konversi energi sebesar $2,77 \times 10^{-2} \%$ [14]. Namun nilai efisiensi konversi dalam penelitian ini masih lebih tinggi dibandingkan dengan yang diperoleh Anita, dkk. yang menggunakan klorofil daun kacang panjang sebagai dye sensitizer, yang hanya mendapat efisiensi konversi energi sebesar $2 \times 10^{-3} \%$ [15]. Masih rendahnya hasil keluaran maupun efisiensi konversi ini disebabkan karena resistansi lapisan elektroda semikonduktor $\mathrm{TiO}_{2}$ dan elektrolit polimer dari sel surya DSSC yang masih terlalu besar. Sehingga jumlah elektron yang mengalir dalam rangkaian menjadi kecil.

\section{SIMPULAN}

Telah difabrikasi prototipe DSSC dengan fotosensitizer dye antosianin strawberry. Sel surya direndam dengan $\mathrm{pH}$ larutan antosianin yang berbeda, yaitu dengan $\mathrm{pH} 3,0 ; 2,5$; dan 2,0. Hasil pengujian sel surya DSSC menunjukkkan bahwa sel surya yang direndam dalam larutan antosianin dengan pH 3,0 memiliki keluaran yang paling rendah, yaitu dengan arus rangkaian pendek $\left(\mathrm{I}_{s c}\right)$ sebesar $21,00 \mu \mathrm{A}$ dan tegangan rangkaian buka $\left(\mathrm{V}_{o c}\right)$ sebesar $3,60 \mathrm{mV}$, serta rapat arus $\left(\mathrm{J}_{s c}\right)$ sebesar $9,34 \mu \mathrm{A} / \mathrm{cm}^{2}$. Dan besarnya efisiensi konversi energi yaitu $0,016 \times 10^{-3} \%$. Sedangkan sel surya yang direndam dalam larutan antosianin dengan $\mathrm{pH}$ 2,0 memiliki keluaran yang paling tinggi, dimana arus rangkaian pendek $\left(\mathrm{I}_{s c}\right)$ yang didapatkan sebesar 45,00 $\mu \mathrm{A}$ dan tegangan rangkaian buka $\left(\mathrm{V}_{o c}\right)$ sebesar $321,00 \mathrm{mV}$, serta besar rapat arus $\left(\mathrm{J}_{s c}\right)$ adalah $20,00 \mu \mathrm{A} / \mathrm{cm}^{2}$, dengan efisiensi konversi energi sebesar 2,560 $\times 10^{-3}$. Dengan demikian terlihat bahwa untuk sel surya DSSC dengan dye antosianin strawberry, semakin rendah $\mathrm{pH}$ larutan ekstrak antosianin strawberry, maka efisiensi konversi energi dari sel surya akan semakin besar.
[1] L. Pancaningtyas, dan S. Akhlus, Peranan Elektrolit pada Performa Sel Surya Pewarna Tersensitisasi (SSPT), Laporan Penelitian, Institut Teknologi Sepuluh Nopember, Surabaya.

[2] Hardeli, dkk., Pembuatan Prototipe Dye Sensitized Solar Cell (DSSC) Menggunakan Ubi Jalar Ungu, Wortel dan Kunyit Sebagai Sumber Zat Warna, Laporan Penelitian, Universitas Negeri Padang, Padang.

[3] M. Grätzel, Journal of Photochemistry and Photobiology, 4, 145153 (2003).

[4] M. Grätzel, C.R. Chimie, 9, 578-583 (2005).

[5] A. Maddu, M. Zuhri, dan Irmansyah, Makara, Teknologi, 11(2), 78-84 (2007).

[6] M.C. Misbachudin, S. Trihandaru, A. Sutresno, Studi Awal Ekstrak Antosianin Strawberry sebagai Fotosensitizer dalam Pembuatan Prototipe Dye Sensitized Solar Cell (DSSC), Seminar Nasional $2^{\text {nd }}$ Lontar Physics Forum, LPF 1350, 2013.

[7] M.C. Misbachudin, S. Trihandaru, A. Sutresno, Pembuatan Prototipe Dye Sensitized Solar Cell (DSSC) Dengan Memanfaatkan Ekstrak Antosianin Strawberry, Seminar Nasional Sains dan Pendidikan Sains VIII, 4(1), 345-350, 2013.

[8] J.M.R.C. Fernando, and G.K.R. Senadeera, Current Science 95(5), 663-666 (2008).
[9] Seafast Center, Merah-Ungu Antosianin, Pewarna Alami untuk Pangan, 23-43, 2012.

[10] W. Septina, dkk., Pembuatan Prototipe Solar Cell Murah dengan Bahan Organik-Inorganik (Dye-sensitized Solar Cell), Laporan Penelitian Bidang Energi, Institut Teknologi Bandung, Bandung, 2007.

[11] G.P. Smestad, and M. Grätzel, J.Chem. Educ., 75, 752-756 (1998).

[12] T. Marinado, Photoelectrochemical studies of dye sensitized solar cells using organic dyes, Kungliga Tekniska Hgskolan, Stockholm, 2009.

[13] M.S.W. Kumara dan G. Prajitno, Studi Awal Fabrikasi Dye Sensitized Solar Cell (DSSC) dengan Menggunakan Ekstraksi Daun Bayam (Amaranthus Hybridus L.) sebagai Dye Sensitizer dengan Variasi Jarak Sumber Cahaya pada DSSC, Laporan Penelitian, Institut Teknologi Sepuluh Nopember, Surabaya, 2012.

[14] E. Jarkko, Chemistry and physics, Kuopion Lyseon lukio (1213).

[15] Anita, dkk., Karakteristik Klorofil Pada Daun Kacang Panjang (Vigna Sinensis) sebagai Dye-Sensitized Solar Cells, Seminar Nasional $2^{\text {nd }}$ Lontar Physics Forum, LPF 1353, 2013. 